\title{
The role of glacier retreat for Swiss hydropower production
}

\section{(running title: Glacier retreat and Swiss hydropower)}

Bettina Schaefli ${ }^{1,2,}$ Pedro Manso ${ }^{2}$, Mauro Fischer ${ }^{3,4}$, Matthias Huss ${ }^{3,5}$ Daniel Farinotti ${ }^{5,6}$

1: Institute of Earth Surface Dynamics, University of Lausanne, Switzerland

2: Laboratory of Hydraulic Constructions, School of Architecture, Civil and Environmental Engineering (ENAC),Ecole Polytechnique Fédérale de Lausanne (EPFL), Switzerland

3: Department of Geosciences, University of Fribourg, Switzerland

4: Department of Geography, University of Zürich, Switzerland

5: Laboratory of Hydraulics, Hydrology and Glaciology, ETH Zurich, Switzerland

6: Swiss Federal Institute for Forest, Snow and Landscape Research (WSL), Birmensdorf, Switzerland

Corresponding author: Bettina Schaefli, bettina.schaefli@unil.ch

UNIL, FGSE-IDYST

Bâtiment Géopolis

1015 Lausanne

Switzerland 


\section{Abstract}

High elevation or high latitude hydropower production (HP) strongly relies on water resources that are influenced by glacier melt and are thus highly sensitive to climate warming. Despite of the wide-spread glacier retreat since the development of HP infrastructure in the $20^{\text {th }}$ century, little quantitative information is available about the role of glacier mass loss for HP. We provide the first regional quantification for the share of Alpine hydropower production that directly relies on the waters released by glacier mass loss, i.e. on depletion of long-term ice storage that cannot be replenished by precipitation in the coming decades. Based on the case of Switzerland (which produces over $50 \%$ of its electricity from hydropower), we show that since $1980,3.0 \%$ to $4.0 \%$ (1.0 to $\left.1.4 \mathrm{TWh} \mathrm{yr}^{-1}\right)$ of the countryscale hydropower production was directly provided by the net glacier mass loss and that this share is likely to reduce substantially by $2040-2060$. For the period 2070-2090, a production

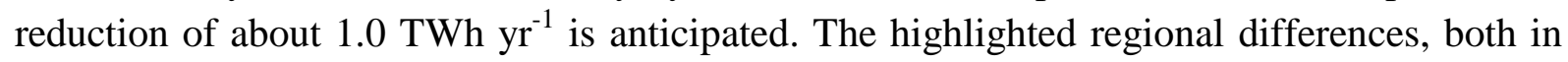
terms of HP share from glacier mass loss and in terms of timing of production decline, emphasize the need for similar analyses in other Alpine or high latitude regions.

Key words: hydrology, glacier mass balance, hydropower, climate change, Alps 


\section{Introduction}

Hydropower provides around 16\% of the world's total electricity (Gernaat et al., 2017). In Europe, hydropower represents around $20 \%$ of the electricity production (Lehner et al., 2005) and high shares of hydropower production (HP) can in particular be found in high latitude and high elevation regions (Lehner et al., 2005), where part of HP relies on water resources that are temporarily stored in the form of snow and ice, and are thus particularly vulnerable to climate warming (Barnett et al., 2005).

Despite the well-known inherent variability of water resources availability, fundamental energy market models (Bauermann et al., 2014) but also large-scale hydropower assessments usually only account for selected baseline water years (Voisin et al., 2016). The notable exception are recent continental to global scale studies of HP potential (Gernaat et al., 2017) or of climate change impact on HP (Hamududu and Killingtveit, 2012;Kao et al., 2015). While giving the broader picture at continental scales, these studies cannot yet adequately resolve the natural variability of water resources at the HP catchment scale or in mountainous regions in general (Schaefli, 2015). Accordingly, the impact of climate warming on HP in snow- and glacier influenced regions still essentially relies on individual case studies (REFERENCE, namely from the Alps and US), with some regional analyses of the effect of climate warming on snow- and glacier influenced HP available for the US (references).

Glacier retreat has in this context long been recognized as potential threat to HP around the world (Bolch et al., 2012;Bradley et al., 2006;Orlove, 2009). Studies quantifying the actual impact of glacier mass loss on HP are, however, extremely rare. Existing impact studies in the Alpine region focus on the quantification of water resources regime changes (Gaudard et al., 2014; Schaefli et al., 2007) rather than on quantifying the impact of actual glacier mass loss on hydropower production, as for example in the work of Vergara et al. (2007) for the tropical Andes. They showed that glacier retreat might reduce HP for the Cañon del Pato HP plant on the Rio Santa by $570 \mathrm{GWh} \mathrm{yr}^{-1}$ if the glacier contribution disappears.

This paper provides, to our knowledge, the first quantification of how HP in an Alpine country, Switzerland, depends on annual glacier mass loss, in the past as well as in the future. The relevance of this study is twofold: i) Swiss HP helps balancing the regional electricity exchanges between France, Germany, Italy and Austria (voltage regulation), guarantees power and frequency modulation (primary, secondary and tertiary controls) and allows for black-start of the regional grid (Beck and Scherer, 2010); ii) Swiss HP can be seen as a reference case for all other Alpine HP regions in Austria, Italy and France namely. The methodology used in this paper is also transferable to northern countries with glacierinfluenced HP.

Hydropower represents around 55\% of the Swiss electricity production, which in 2015 was 61.6 TWh (Swiss Federal Office for Energy, 2017c). All large Swiss rivers and many smaller rivers used for HP are influenced by meltwater from seasonal snow cover and glaciers. To understand the role of glacier retreat for HP, the key variable is the amount of water that originated from annual glacier mass loss. This number is usually unknown but can be estimated based on observations of the key water balance components, i.e. precipitation and streamflow (Section 3). The recent work of Fischer et al. (2015) - who estimated annual mass changes for all glaciers in Switzerland during 1980-2010 - represents a unique opportunity to obtain insights into the role of glaciers for the Swiss water resources. 
In this paper, we combine the above estimates with Swiss-wide data for water resources (Pfaundler and Zappa, 2008), glacier runoff simulations (Huss and Hock, 2015) and the spatial database on Swiss hydropower plants developed by (Balmer, 2012) to quantify the role of glaciers for HP in Switzerland. By doing so, we provide the first quantitative assessment for the share of HP that can be attributed to annual glacier mass loss and how this share might evolve in the future owing to changes in water availability from glacier melt.

\section{Swiss water resources and HP}

\subsection{Overview}

The average available water for Switzerland (total water volume divided by area) over the $20^{\text {th }}$ century was around $1300 \mathrm{~mm} \mathrm{yr}^{-1}$ (Blanc and Schädler, 2013). Recent estimates of glacier mass change for all Swiss glaciers indicate a net change between 1980 and 2010 of $-620 \mathrm{~mm}$ $\mathrm{yr}^{-1}$ (relative to the glacier area in 2010, i.e. $944 \mathrm{~km}^{2}$ ) (Fischer et al., 2015). This corresponds to $-14 \mathrm{~mm} \mathrm{yr}^{-1}$ when averaged over the area of Switzerland. While this number seems spurious on the annual level, it is not negligible in terms of monthly water availability (Huss, 2011). More importantly, this apparently small number represents a water input for hydropower production that does not originate from this year's rainfall but from water accumulated decades to centuries ago.

\subsection{Hydrological regimes}

The temporal distribution of streamflow, or the streamflow regime, is key to understand the interplay of glacier melt water and HP. The streamflow regimes of Switzerland (Figure 1) are of two fundamentally different types (Weingartner and Aschwanden, 1992;Hänggi and Weingartner, 2012): (i) snow- or glacier-dominated regimes that show a pronounced low flow during winter (due to the freezing conditions) and much higher flows during the melt months (April-August), and (ii) rainfall-dominated regimes, where streamflow follows the seasonality of rainfall and of evapotranspiration (resulting in typical summer low flows). An overview of the spatial distribution of streamflow amounts is given in the Supplementary Material (Figure S1).

With anticipated atmospheric warming over the coming decades, major changes in the streamflow regime of snow- and glacier-fed drainage basins are expected (e.g. Barnett et al., 2005). As glaciers retreat, they release water from long-term storage, contributing thereby to a transient increase in annual streamflow for a few decades (e.g. Huss et al., 2008). The timing of maximum glacier melt volumes depends on the characteristics (elevation range, ice volume) of the catchment and the rate of climate change (Farinotti et al., 2012). In mountainous catchments, significant shifts in the hydrological regime are expected with increasing streamflow in spring and early summer and declining streamflow in July and August (Horton et al., 2006;Finger et al., 2012;Addor et al., 2014). These changes result from an earlier onset of the snow melting season and from shrinking glacier areas. 


\subsection{Swiss hydropower infrastructure}

The Swiss HP infrastructure in the year 2016 was composed of 662 powerhouses (Swiss Federal Office for Energy, 2017b) and 195 large dams that are under the direct supervision of the Swiss federal government (Swiss Federal Office for Energy, 2017a). The average annual HP was 35.7 $\mathrm{TWh} \mathrm{yr}^{-1}$ for the period 1980-2016 (Table 1). The spatial distribution of the HP schemes is conditioned by the discussed specificities of the Swiss hydrological regimes (Figure 2): the southern and central mountain regions host most of the storage HP schemes; the large run-of-the-river (RoR) schemes are located on the lowland rivers.

\section{Classification of HP infrastructure}

The Swiss HP infrastructure can be divided into three main groups (Manso et al., 2015) (Figure 2). Group 1 includes large storage schemes that shift large amounts of meltwater inflows from summer to winter to buffer winter droughts. The group mostly consists of highhead (>100 m) storage schemes with one or several reservoirs (e.g. the well-known Grande Dixence with its storage reservoir of $40110^{6} \mathrm{~m}^{3}$ ). These reservoirs have typically natural catchment areas of between 50 and $150 \mathrm{~km}^{2}$ and waterways draining water from additional, distant catchments. Most group 1 schemes show periods in which their reservoir is full and during which they are operated as run-of-the-river schemes.

Group 2 includes low-head (a few tens of meters) RoR schemes with large catchments $\left(>2500 \mathrm{~km}^{2}\right.$ ) with a typical installed capacity between $5 \mathrm{MW}$ and $100 \mathrm{MW}$, built on large lowland rivers close to urban and industrial areas. The hydrologic regime of these rivers is strongly influenced by artificial or natural lakes and water management upstream.

Group 3 includes both low-head and high-head RoR schemes with catchments $<2500 \mathbf{~ k m}^{2}$. Contrary to low-head schemes, high-head RoR schemes (with heads from 100 to $1100 \mathrm{~m}$ ) by-pass a given river-reach and usually have installed capacity below $30 \mathrm{MW}$. Schemes of group 2 and 3 usually have marginal storage capacity.

A special case are pumped-storage HP schemes that operate between one or two in-stream reservoirs (semi-open or open-loop pumped-storage). The number of such schemes might increase in the near future as a means for grid regulation (Gurung et al., 2016). They are not discussed separately here. It is noteworthy that both Group 1 and 3 include schemes that transfer water across the natural boarders of the major European rivers (e.g. the Gries HP scheme from the Rhone to the Po basin, the Hongrin scheme from Rhine to Rhone or the Totensee scheme from Rhone to Rhine).

\subsection{Climate change impact projections on HP}

Numerous studies quantified the effect of climate change on Swiss HP with a so-called climate change impact modeling chain (Schaefli, 2015). These studies have a strong focus on high Alpine HP (Farinotti et al., 2012;Fatichi et al., 2015; Finger et al., 2012; Terrier et al., 2015). Only few studies exist on HP in lowland rivers (for an example, see, Hänggi and Weingartner, 2012;Wagner et al., 2016). While the earliest studies (Horton et al., 2006; Schaefli et al., 2007) made very rough assumptions about the evolution of glacierized surfaces, recent work highlighted the importance of more detailed parameterizations of glacier 
surface evolution (Huss et al., 2010) and of reliable estimates of initial ice volumes (Gabbi et al., 2012).

The latest comprehensive analysis of climate change impact on Swiss HP was elaborated in the context of two research projects, CCHydro funded by the Swiss Federal Office for the Environment (FOEN, 2012) and CCWasserkraft (SGHL and CHy, 2011) funded by Swisselectric research and the Federal Office for Energy. In agreement with all previous results, these analyses of 50 representative Swiss catchments for the periods 2021-2050 and 2070-2099 concluded that the ongoing warming in the Alps will significantly decrease both the snow cover duration at all altitudes and the maximum annual snow accumulation at high elevations. As a result, Swiss glaciers will strongly reduce in surface by 2100 . The combined effect of a reduced snowfall-to-rainfall ratio and of warmer spring temperatures will shift the annual maximum monthly streamflow of snow-dominated rivers to earlier periods in the year (up to several weeks). At the same time the snowmelt induced high flows might be more concentrated in time. The concomitant glacier melt will result in a temporary increase of annual streamflow but ultimately lead to reduced annual flows in glacier-influenced catchments, with reduced flows in late summer (e.g. Farinotti et al., 2016).

In general, late summer streamflow will be reduced in all snow-influenced catchments due to the earlier melting season. For non-glacierized catchments, the annual flow might slightly decrease by 2100 due to a warming-related increase of evapotranspiration and a potential (small) decrease of precipitation. For a comprehensive overview of projected changes, see the work of Speich et al. (2015).

The amplitude of changes remains, however, highly uncertain due to uncertainties in both modelling and initial ice volume (Huss et al., 2014). An assessment of the volumes of all Swiss glaciers with ground-penetrating radar (Langhammer et al., 2017) is ongoing in the context of research for the Swiss energy transition (Schleiss, 2014).

\section{Data sets}

The detailed analysis of the role of glaciers for HP is based on five data sets: (i) a GIS database of the Swiss HP infrastructure (HYDROGIS, Balmer, 2012), (ii) the Swiss hydropower production statistics (Swiss Federal Office for Energy, 2016), (iii) monthly natural streamflows of the Swiss river network (Zappa et al., 2012), (iv) estimated glacier mass changes between 1980 and 2010 (Fischer et al., 2015), and (v) simulated past and future glacier runoff for all individual Swiss glaciers (Huss and Hock, 2015).

\subsection{Hydropower infrastructure: HYDROGIS}

The GIS data base developed by M. Balmer (Balmer, 2012) includes 401 powerhouses corresponding to a total installed power of $14.5 \mathrm{GW}$ out of the total of $15.0 \mathrm{GW}$ installed in 2005. In 2016, the total installed power was 16.2 GW.. During the same time, the total expected production increased from 38.7 GWh to $39.9 \mathrm{GWh}$ (Swiss Federal Office for Energy, 2016). 
In HYDROGIS, the powerhouses are characterized by their production type (RoR, storage or pump-storage) and for most of them, the installed power and the turbine design discharge are known. Information on the feeding catchments is, however, not available at the powerhouse level since the 401 powerhouses are grouped into $284 \mathrm{HP}$ schemes, which is the reference level for HP catchment information. The database includes furthermore 214 HP reservoirs, 119 dams and 787 water intakes.

For the present analysis, the most important added value of HYDROGIS is the connection between HP schemes and catchments, which was compiled by Balmer (2012) via a detailed analysis of adduction tunnels and of company reports of all schemes. Detailed checks showed that the database is reliable in terms of connections between catchments and HP schemes, which is the basis for the water resources analysis herein.

\subsection{Hydropower production statistics}

Hydropower production statistics are available from the yearly electricity statistics of Switzerland (Swiss Federal Office for Energy, 2017c) aggregated to six large regions: (i) Ticino, (ii) Grisons, (iii) Valais, (iv) Northern Alps, (iv) Jura, (vi) Plateau (for the correspondence of these regions to main Swiss river catchments see Table S1). Besides actual annual production, the statistics contain annual production potentials, which have to be reported by HP companies for water tax purposes. The production potential is used here as an estimate of the total annual amount of water that was available for production in the catchments (whether used or not).

\subsection{Natural streamflow of Swiss rivers}

The Swiss Federal Office for the Environment (FOEN) (Swiss Federal Office for the Environment, 2016) provides a Swiss-wide raster data set (500 m x $500 \mathrm{~m})$ with simulated monthly natural streamflows. This data has been shown to give relatively unbiased estimates of the monthly flows if aggregated to areas between $10 \mathrm{~km}^{2}-1000 \mathrm{~km}^{2}$ (beyond this scale, large lakes might bias the results) (Pfaundler and Zappa, 2008). We use here the latest version of the data, made available by Zappa et al. (2012). It covers the period 1981-2000, which thus serves as reference period for all presented analyses.

\subsection{Mass changes of Swiss glaciers}

Geodetic mass changes between 1980 and 2010 are available for all glacier-covered HP catchments from Fischer et al. (2015). Corresponding glacier outlines are taken from the Swiss Glacier Inventory SGI2010(Fischer et al., 2014).

Between 1980 and 2010, the estimated average geodetic mass balance for the entire Swiss Alps was $-620 \mathrm{~mm}$ water equivalent (w.e.) $\mathrm{yr}^{-1}$, with remarkable regional differences (Table 4).

\subsection{Glacier runoff}

\section{Present and future glacier runoff}

For each individual glacier, past and future glacier mass balance, surface geometry change and retreat, and monthly runoff is available from the Global Glacier Evolution Model 
(GloGEM, Huss and Hock, 2015). The model has been forced with ERA-interim climate reanalysis data (Dee et al., 2011) for the past and with 14 Global Circulation Models and three different $\mathrm{CO}_{2}$-emission pathways (Taylor et al., 2012) until 2100. For the purpose of the present paper, we define glacier runoff as all water exiting the glacier during one month (for details, see the Supplementary Material).

The future glacier runoff simulations from GloGEM show the expected decrease of glacier runoff in the period 2040-2060 for catchments with low glacier coverage. For the period 2070 - 2090, the simulations show a consistent decrease of glacier runoff for all HP catchments (Figure S2 and Farinotti et al., 2016).

\section{Methods}

We give hereafter details on how HP is estimated at different scales based on discharge data for different time periods, followed by details on the assessment of past and future HP from annual glacier mass loss and of expected HP changes resulting from hydrologic regime modifications.

\subsection{Estimation of HP production at the scheme scale}

The HP data available at the powerhouse level includes the expected annual electricity

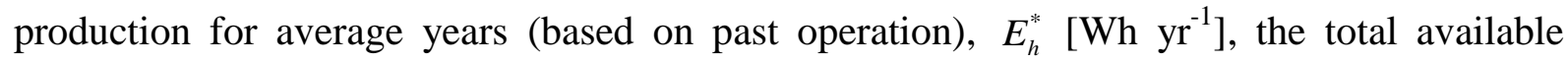
power, $P_{h}^{*}[\mathrm{~W}]$, and the total design discharge through the turbines, $Q_{h}^{*}\left[\mathrm{~m}^{3} \mathrm{~s}^{-1}\right]$, where $h$ designates the (power)house level. A first order estimate of the number of powerhouse operating hours, $\tau_{h}^{*}\left[\mathrm{~h} \mathrm{yr}^{-1}\right]$, can thus be obtained as:

$$
\tau_{h}^{*}=\frac{E_{h}^{*}}{P_{h}^{*}}
$$

The asterisk (*) is used to identify design variables and not actual time-varying quantities. Note that the estimate neglects the percentage of time that only part of the powerhouse capacity is used (i.e. not all turbines in use or at partial load).

Based on $\tau_{h}^{*}$, we estimate a first lumped water-to-electricity conversion factor, called electricity coefficient, $\gamma_{h}^{*}\left[\mathrm{kWh} \mathrm{m}^{-3}\right]$ as follows:

$$
\gamma_{h}^{*}=\frac{E_{h}^{*}}{Q_{h}^{*} \tau_{h}^{*} 3600 \cdot 10^{3}}=\frac{P_{h}^{*}}{Q_{h}^{*} 3600 \cdot 10^{3}} .
$$

The electricity coefficients obtained at the scale of the powerhouses, $\gamma_{h}^{*}$, can be summed up to the scale of the HP schemes:

$$
\gamma_{j}^{*}=\sum_{\forall h \in j} \gamma_{h}^{*}
$$

where $\gamma_{j}^{*}$ is the electricity coefficient of scheme $j$. 
This electricity coefficient $\gamma_{j}^{*}$ relates indirectly the average annual streamflow available from the catchment $Q_{j}\left[\mathrm{~m}^{3} \mathrm{~s}^{-1}\right]$ to the corresponding electricity production at the scheme level, based on the past average electricity production. However, not all powerhouses within a catchment use the water of the entire catchment and the catchments corresponding to each powerhouse are unknown. We thus assume that the design discharge for each powerhouse, $Q_{h}^{*}$, multiplied by the expected operation hours, $\tau_{h}^{*}$, is representative of the amount of annual water that feeds this powerhouse. This assumption is adequate for storage plants, which mostly operate in design conditions. For RoR schemes this assumption leads to underestimating the operation hours and overestimating the electricity coefficient.

Accordingly, we propose to use the following weighted scheme-scale electricity coefficient $\widehat{\gamma_{j}}:$

$$
\widehat{\gamma_{j}}=\frac{\sum_{\forall h \in j} E_{h}^{*}}{3600 \sum_{\forall h \in j} Q_{h}^{*} \tau_{h}^{*}}=\frac{\sum_{\forall h \in j} \gamma_{h}^{*} Q_{h}^{*} \tau_{h}^{*}}{\sum_{\forall h \in j} Q_{h}^{*} \tau_{h}^{*}},
$$

Actual discharge time series for different time periods are available at the catchment-scale only. An estimate of the discharge $Q_{h i}$ feeding each powerhouse $h$ over time period $i$ is obtained as:

$Q_{h i}=Q_{i j} \frac{Q_{h}^{*}}{\sum_{\forall h \in j} Q_{h}^{*}}$,

where $Q_{i j}\left[\mathrm{~m}^{3} \mathrm{~s}^{-1}\right]$ is the average annual discharge available for the scheme catchment $j$ during time period $i$.

The weighted scheme-scale electricity coefficient is the key to estimate HP from annual glacier mass loss for past and future time periods at the scheme-scale.

\subsection{Estimation of HP production at the regional scale}

The electricity statistics also report production statistics for subregions of Switzerland. To obtain a regional-scale electricity coefficient $\hat{\gamma}_{r}\left[\mathrm{kWh} \mathrm{m}^{-3}\right]$ for region $r$, the scheme-scale electricity coefficients are weighted according to their expected total production (a flow-time scaling is not possible since the concept of operating hours does not make sense at the scheme scale):

$$
\widehat{\gamma_{r}}=\frac{\sum_{\forall j \in r} \widehat{\gamma_{j} E_{j}^{*}}}{\sum_{\forall j \in r} E_{j}^{*}} .
$$


Where $E_{j}^{*}=\sum_{\forall h \in j} E_{h}^{*}$ is the expected production at the scheme level. This regional-scale electricity coefficient expresses how much water is produced from a $\mathrm{m}^{3}$ of water flow that is originating in that region.

\subsection{Estimation of HP production at the network scale}

Changing the perspective from the hydropower producing catchment to a hydropower producing river reach, we can estimate a weighted electricity coefficient $\widehat{\gamma}_{x}$ at a given network location $x$ :

$\widehat{\gamma_{x}}=\frac{\sum_{\forall h \text { upstream } x} E_{h}^{*}}{3600 \sum_{\forall \text { upstream } x} Q_{h}^{*} \tau_{h}^{*}}=\frac{\sum_{\forall h \text { upstream } x} \gamma_{h}^{*} Q_{h}^{*} \tau_{h}^{*}}{\sum_{\forall \text { upstream } x} Q_{h}^{*} \tau_{h}^{*}}$.

While $\widehat{\gamma_{j}}$ expresses how much hydropower is produced from $\mathrm{a} \mathrm{m}^{3}$ of water flow generated in a catchment, this point-scale electricity coefficient, $\widehat{\gamma_{x}}$, expresses how much electricity is generated per $\mathrm{m}^{3}$ of water that transits a given location in a river.

The total hydropower production of the entire network upstream of location $x$ for period $i$ is then obtained as:

$$
E_{i x}=3600 \cdot 10^{3} \sum_{\forall \text { upstream } x} \gamma_{h}^{*} Q_{i h} \tau_{h}^{*} .
$$

\subsection{Analysis of past and future water resources availability from annual glacier mass loss}

Based on the observed data of Fischer et al. (2014;2015), we propose to estimate the share of water resources that results from glacier mass depletion, $\rho_{i j}$, at the scale of all HP scheme catchments as follows:

$\rho_{i j}=\frac{m_{i j}}{q_{i j}}$,

where $m_{i j}\left[\mathrm{~mm} \mathrm{yr}^{-1}\right]$ is the average annual glacier mass loss in catchment $j$ over period $i$, and $q_{i j}\left[\mathrm{~mm} \mathrm{yr}^{-1}\right]$ is the specific discharge of catchment $j$ (discharge in $\mathrm{m}^{3} \mathrm{~s}^{-1}$ divided by the catchment area). Given the assumed linear relationship between annual HP, $E_{i j}$, and available discharge (Equation 7), $\rho_{i j}$ gives a direct estimate of the share of annual HP that results from glacier mass depletion.

Discharge and ice melt data are available for the following periods: $\mathrm{T}_{\text {ref }}=1981-2000$, $T_{1}=2040-2060$ and $T_{2}=2070-2090$. In addition, some results are reported for the time period 1980-2010, which is the original reference period for the mass balance data published by Fischer et al. (2015). 


\subsection{Future regime impacts on HP}

Climate change induced modifications of glacier runoff affect the water availability in terms of quantity and temporal occurrence (an example of future simulated glacier runoff is given in Figure 3). We quantify the effect of regime modifications on HP in terms of the absolute difference of the runoff volume from the glacier-covered area between two time periods for each month $m$ :

$V_{i j}^{g}(m)=\left|Q_{i j}^{g}(m)-Q_{\mathrm{ref}, j}^{g}(m)\right| \Delta t$,

where $V_{i j}^{g}(m)\left[\mathrm{m}^{3}\right]$ is the glacier $(g)$ runoff volume difference for month $m$, time period $i$ and catchment $j, Q_{i j}^{g}(m)\left[\mathrm{m}^{3} \mathrm{~s}^{-1}\right]$ is the monthly simulated glacier runoff of time period $i$, and $Q_{\mathrm{ref}, j}^{g}(m)\left[\mathrm{m}^{3} \mathrm{~s}^{-1}\right]$ is the monthly glacier runoff for the reference period. $\Delta_{m}[\mathrm{~s}]$ is the duration of the month. The reference area for $V_{i j}^{g}, Q_{i j}^{g}$, and $Q_{\text {ref } j}^{g}$ is the glacier-covered area during the reference period. For future periods, in which glaciers have retreated, this area will notably include ice-free surfaces as well.

A glacier runoff change indicator $\delta_{i j}$ is obtained by (i) normalizing $V_{i j}^{g}(m)$ to the total catchment discharge $Q_{\text {ref }, j}(m)$ for the reference period and (ii) averaging over all months (see Figure S3 for an illustration):

$$
\delta_{i j}=\sum_{m=1}^{12} \frac{V_{i j}(m)}{Q_{\mathrm{ref}, j}(m) \Delta_{m}} .
$$

As for the share of electricity production resulting from glacier mass depletion $\left(\rho_{i j}\right), \delta_{i j}$ can be directly interpreted in terms of HP: it gives the relative amount of annual hydropower that, for period $i$, is available during a different period of the year than for the reference period.

\section{Results}

\subsection{Swiss HP overview}

The Swiss HP schemes use the water of an area of $39,740 \mathrm{~km}^{2}$, corresponding to $93 \%$ of the Swiss territory and including all Swiss glaciers. The large percentage is due to the run-of-river (RoR) HP schemes in series on all large rivers leaving Switzerland (Figure 2 and Table S2). The cumulative sum of all HP scheme catchments amounts to $528,278 \mathrm{~km}^{2}$ or roughly 13 times the total catchment area (Table 2), which emphasizes the degree of nesting of the HP catchments, in particular in low-lying areas (Plateau region, North of the Alpes region).

On average, the water from the 134 headwater catchments is used in 12 HP stages, with 12 headwater catchments that are not part of a larger production network. The water from some Alpine headwater catchments is used in up to $30 \mathrm{HP}$ stages down to the Rhine in Basel. 


\subsection{Natural variability of Swiss HP resources}

Measured in terms of production potential, the six major HP regions (Table 2) show important differences in interannual variability of available water (Figure 4a), with coefficients of variations (standard deviation divided by the mean) ranging from 0.06 to 0.16 . The interannual variability of precipitation (Figure 4b), in contrast, is rather similar across all regions, with a coefficient of variation between 0.10 and 0.11 .

The lowest variability of the production potential is obtained for the region with the highest glacierization (Valais, Figure 4c) and for the Plateau region (Figure 4e). For the Valais, as for other areas with a high glacierization, the glaciers act as a strong buffer of interannual variability. This notably results in a relatively stable interannual operation of high elevation HP reservoirs across Switzerland (see Hänggi and Weingartner, 2012, including an illustration of Swiss reservoir filling curves).

The low variability of the production potential of the Plateau region can be explained by the large number of RoR power plants with large catchments, for which the spatial precipitation variability averages out. At the Swiss scale, the low variability of the production potential results from an averaging effect across regions.

\subsection{Electricity coefficients from the scheme scale to the regional scale}

Swiss HP infrastructure shows high electricity coefficients, with an average electricity coefficient of the analyzed powerhouses of $0.63 \mathrm{kWh} \mathrm{m}^{-3}$ and an average scheme scale electricity coefficient of $0.59 \mathrm{kWh} \mathrm{m}^{-3}$ (Table 3). For individual schemes, the values range from $0.004 \mathrm{kWh} \mathrm{m}^{-3}$ for lowland RoR schemes to up to $4.44 \mathrm{kWh} \mathrm{m}^{-3}$ for the single-stage high-head Cleuson- Dixence HP scheme (Figure 5).

The overall high scheme-scale electricity coefficients are explained by the high electricity coefficients of headwater catchments, with an average of $0.95 \mathrm{kWh} \mathrm{m}^{-3}$ (Figure 5a). Three of these headwater schemes have both a particularly high head with their powerhouses located at low elevation in the Rhone valley bottom and high elevation catchments, resulting in electricity coefficients above $3 \mathrm{kWh} \mathrm{m}^{-3}$ (Figure 5a).

At the level of the electricity statistics regions, a generally strong elevation trend of electricity coefficients becomes visible (Figure $5 \mathrm{~b}$ ). The trend is of $1.00 \mathrm{kWh} \mathrm{m}^{-3}$ per $1000 \mathrm{~m}$ of increase of the mean catchment elevation. This Swiss-wide trend can be converted into a rough estimate of the electricity coefficient of HP from glacier melt water: given the mean elevation of the Swiss glaciers by 2010, $3042 \mathrm{~m}$ asl ), the general elevation trend of regional electricity coefficients (Figure 5b) yields an electricity coefficient of $1.0010^{-3} \mathrm{kWh} \mathrm{m}^{-3} \mathrm{~m}^{-1} \times 3042 \mathrm{~m} \mathrm{-}$ $0.940 \mathrm{kWh} \mathrm{m}^{-3}=2.11 \mathrm{kWh} \mathrm{m}^{-3}$ (see Section 5.5 for further details).

\subsection{Electricity coefficients at the network scale}

The effect of having sequences of HP schemes along rivers can be illustrated based on the two largest river networks, the one of the Rhine and of the Rhone (Figure 2). The Rhine network has a weighted electricity coefficient of $0.04 \mathrm{kWh} \mathrm{m}-3$, which is twice as high as the electricity coefficient of the hydropower plant operating on the Rhine at its Swiss outlet (Birsfelden), which equals $\gamma_{h}=0.02 \mathrm{kWh} \mathrm{m}^{-3}$ (Table 3). For the Rhone catchment, including 
many high-head hydropower plants and with water being used in up to 9 stages, the weighted electricity coefficient of the entire network equals $0.27 \mathrm{kWh} \mathrm{m}^{-3}$, which is more than 10 times the electricity coefficient of the powerhouse on the Rhone at its Swiss outlet (at ChancyPougny, $0.02 \mathrm{kWh} \mathrm{m}^{-3}$ ).

\subsection{Estimation of HP production from annual glacier mass loss}

The high elevation HP schemes receive a significant amount of water input from annual glacier mass change, up to $500 \mathrm{~mm} \mathrm{yr}^{-1}$ (relative to the scheme catchment area) for 19812000, or more than $25 \%$ of the total annual catchment discharge (Figure 7).

On a Swiss-wide area-average, the glaciers' net contribution was of $479 \mathrm{~mm}$ w.e. $\mathrm{yr}^{-1}$ for 1981-2000 (Table 4). During this period, the average Swiss glacier cover was $1111 \mathrm{~km}^{2}$ (assuming a linear retreat of the glacier area between 1973 and 2010) (Fischer et al., 2015). A first rough estimate of the HP originating from annual glacier mass loss can be obtained with the regional electricity coefficient extrapolated to the mean glacier elevation. The corresponding production over 1981-2000 equals thus $0.479 \mathrm{~m} \mathrm{yr}^{-1} \times 111110^{6} \mathrm{~m}^{2} \times 2.11$

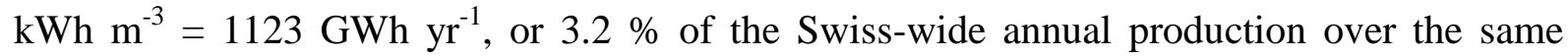
period, which was 34,738 $\mathrm{GWh} \mathrm{yr}^{-1}$ (Swiss Federal Office for Energy, 2016). For the period 1980 - 2010, which had a stronger annual glacier mass loss (Table 4), this ratio equals $4.0 \%$ (Table 5).

This estimation of HP ratios from glacier mass loss relies on two numbers: the average annual glacier mass loss and the electricity coefficient estimated from design data (expected annual production, production time and turbine flow). The annual glacier mass loss has an uncertainty of $+/-0.07 \mathrm{~m} \mathrm{yr}^{-1}$ (Fischer et al., 2015). For the interpolated area of individual glaciers between observation dates, an error of $+/-5 \%$ can be assumed as a conservative estimate. The $95 \%$ confidence interval of the electricity coefficient interpolated at the Swissscale for glaciers (from linear regression analysis) is $2.11+/-0.68 \mathrm{kWh} \mathrm{m}^{-3}$. Inserting these uncertainties into the above regional estimate of HP from glacier-covered areas results in estimated HP from annual glacier mass loss of between $1.8 \%$ and $5.2 \%$ for the period 1980 to 2000 and $2.3 \%$ to $6.2 \%$ for the period 1981 to 2010 .

HP calculations based on scheme-scale melt ratios (Figure 8a) gives very similar estimates: the production ratio $\rho_{i j}$ averaged over all glacier schemes, weighted by the expected scheme production, equals 3.2\% for the period 1981-2000 and 4.0\% for 1980-2010 (Table 5). These Swiss-wide averages of HP production ratios from glacier mass loss hide significant regional differences, with estimates for the past periods ranging from between 6.4 and $7.8 \%$ for the Rhone river to between $1.8 \%$ and $2.2 \%$ for the Rhine river (Table 5).

For the future, the GloGEM simulations predict that $55 \%$ and $79 \%$ of the 2010 glacier volume will be lost by 2040-2060 and 2070-2090, respectively (Table S3). The strong reduction from 2010 to 2040-2060 is coherent with the observed loss of $37 \%\left(22.5 \mathrm{~km}^{3}\right)$ over the period 1980-2010 (the estimated glacier volume for 2010 was of $59.9 \mathrm{~km}^{3}$; (Fischer et al., 2015). The corresponding simulated annual glacier mass loss rates at the scheme-scale result in an average $\rho_{i j}$, of $2.5 \%$ for 2040-2060 (Figure 8c) and of 1.2\% for 2070-2090 (average over glacier schemes, (Table 5). 
The maps of $\rho_{i j}$ (Figure 8c,d) reveal that, in the past, annual glacier mass loss was an important source of water for HP at larger scales and not only in the headwater catchments. Given the strong glacier retreat, the input from annual glacier mass loss is, however, significantly reduced in future simulations . For the Rhine river, input from annual glacier mass loss is likely to become insignificant in the future (Table 5).

For the Rhone river catchment, the simulations suggest that the decrease in HP from annual glacier mass loss might only occur after the period 2040-2060. The contributions, however, will remain significant for this century, with 3.8\% estimated for the period 2070-2090 (Table $5)$.

\subsection{Impacts of glacier runoff regime changes}

Future runoff from glacier catchments is, on average, expected to shift to earlier periods in the year, especially for catchments with important glacier volume loss. The simulated glacier runoff shifts, as summarized by the indicator $\delta_{i j}$, correspond mostly to less than $10 \%$ of the scheme-scale discharges. This is true for both periods 2040-2060 and 2070-2090 (Figure 9). The notable exception are a few run-of-river schemes that are located at elevations higher than $1400 \mathrm{~m}$ asl.. Here, shifts go up to 35\% for the period 2040-2060. Given the strong simulated glacier retreat up to then, the regimes shift only slightly beyond this period.

\section{Discussion}

The method proposed in this paper to analyze the impact of glacier retreat on HP brings together a number of data sets that have not been analyzed jointly so far. In particular, it combines recent model results on glacier mass evolution, estimates for glacier runoff and catchment-scale river discharge, as well as statistics and spatial information on hydropower infrastructure. The contribution of annual glacier mass change to HP is estimated in two different ways: either (a) by estimating and averaging ratios of annual glacier mass loss and total discharge for all HP scheme catchments, or (b) from an elevation-dependent electricity production factor and the mean glacier elevation. Whilst the first method relies on discharge estimates that are based on simulations and observations, the second only relies on observed glacier mass balance data and interpolated electricity coefficients.

Both methods give similar results for the share of HP resulting from the depletion of glacier mass, with Swiss-wide average estimates ranging from $3.1 \%$ to $4.0 \%$ for the observation periods. The relevance of this result is twofold: i) In terms of transferability of the proposed method, the obtained results suggest that similar analyses could be completed in any region that has detailed glacier mass balance data and spatial information on electricity coefficients. ii) For Switzerland, the estimated ratios give a robust estimate of the amount of Swiss-wide HP that originated from annual glacier mass loss in the recent past. It has to be noted that these numbers are considerably higher than the simple average share (not weighted by production) of water originating from glacier mass depletion in the various scheme catchments. The latter, in fact, amounts to only between $1.3 \%$ and $1.7 \%$ (Table 4). This almost doubling effect between the average ratio of water availability from glacier mass depletion and the corresponding average ratio of HP is a direct consequence of using the 
glacier melt water several times along the river network and of the high electricity coefficients associated with glacier water resources.

The simulations suggest that, on a Swiss-wide basis, HP might receive a significantly lower share of water from annual glacier mass loss already in the near future. Compared to 19812000 , the future simulations predict a reduction of the HP ratios from $3.1 \%$ to $2.5 \%$ for the period 2040-2060 and to $1.2 \%$ for 2070-2090. This corresponds to a production reduction of around 0.56 $\mathrm{TWh} \mathrm{yr}^{-1}$ for 2040-2060 and of around 1.00 $\mathrm{TWh} \mathrm{yr}^{-1}$ for 2070-2090.

This share of HP from glacier mass depletion has to be put into relation to other changes expected for HP in the near future. HP is namely expected to decrease by $1.4 \mathrm{TWh} \mathrm{yr}^{-1}$ due to the implementation of the Swiss water protection act during concession renewals (Tonka, 2015; Schleiss, 2014). This is in contrast to the Swiss Energy Strategy 2050, that plans a net

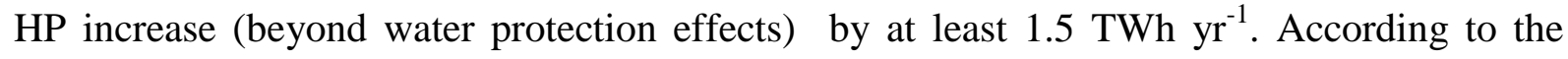
same strategy, this should be obtained by building new small hydropower plants $(+1.3 \mathrm{TWh}$ $\mathrm{yr}^{-1}$ ) and from the extension and adaptation of existing large plants $\left(+0.9 \mathrm{TWh} \mathrm{yr}^{-1}\right)$ (Manso et al., 2015;Schleiss, 2014), which is challenging given that all major Swiss river systems are already exploited (Manso et al., 2015).

The reduction of annual melt water might well be the dominant warming-induced impact for many schemes. The presented analysis shows, however, that for most schemes, the future temporal pattern of glacier melt water inflow will result in a redistribution of less than $10 \%$ of the total available water. In other terms, the annual HP pattern will not fundamentally change for those schemes. It must be noted, however, that this does not applies to RoR schemes that have catchments currently exhibiting an important degree of glacier coverage. Such schemes might in fact experience a profound modification of their water inflow regime already in the near future.

Given the individual character of HP schemes, a more detailed analysis of the temporal redistribution of melt water flows is challenging and would require a detailed analysis at the level of water intakes. Some water intakes might e.g. lose water during future melt periods if the melt water flow is more concentrated on shorter periods and thus exceeds the intake capacity (resulting in a potential increase of overspill duration and magnitude). This might in particular affect glacier-influenced storage HP schemes that usually have a high number of water intakes (e.g. the Grande Dixence scheme has $100 \mathrm{~km}$ of tunnels to route the water of 75 water intakes to its main reservoir; (Grande Dixence, 2010). The Swiss-wide database on water intakes (which includes 1406 HPP intakes, Kummer et al., 2007, p. 22) is, however, known to be incomplete and contains essentially the intakes that are directly relevant for residual flows.

A third implication of climate warming for glacier-influenced HP is a potential modification of the year-to-year variability of available water. This modification is anticipated in many climate change impact studies in high Alpine environments (Horton et al., 2006). With the average monthly flow data used in this study, no further assessment of this important aspect is possible. However, the analyses presented for the annual hydropower production potential (quantifying the production potential) and for the annual precipitation variability at a regional scale shows that there is no clear link between the today's amounts of glacier cover and the 
annual variability in the production potential. This result is unexpected since HP regions with a high glacier cover were previously thought to show a relatively low year-to-year variability of hydropower production potential (Hänggi and Weingartner, 2012). Understanding in detail how the HP network structure buffers current year-to-year precipitation variability and how this might evolve in the future is left for future research.

\section{Conclusion}

Alpine hydropower production (HP) is benefitting from glacier water resources that have been accumulated decades and centuries ago, and that cannot be replenished in the near future. This first quantification of the HP share originating from annual glacier mass loss at the scale of an Alpine region reveals that $3.1 \%$ to $4 \%$ of the total annual Swiss HP presently originates from this transient water resource. The share will rapidly decline for all Swiss regions, resulting in

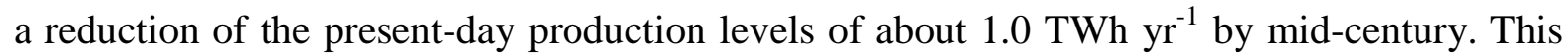

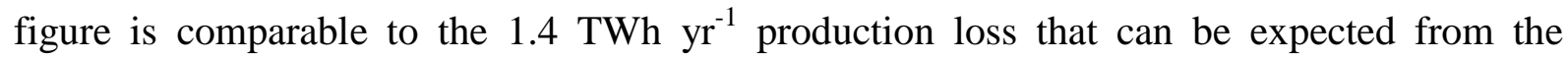
implementation of the new Swiss water protection act (Tonka, 2015;Schleiss, 2014). An exception is given for the Rhone river catchment, in which the relatively large amount of glaciers will continue to provide increased amounts of meltwater at least until the late 2040s.

Despite of observational uncertainties, we have shown that the presented estimates are robust. We anticipate our results to have direct implications for national HP infrastructure projects, such as storage increase at high elevation sites or multipurpose projects combining HP and the regulation of interannual hydrological variability.

Beyond the scale of the analyzed case study, the relevance of our results can be summarized as follows: First of all, the results for Switzerland show that the impact of glacier retreat on HP can be reliably estimated from regional electricity coefficient trends, which here was shown to be of around $1.0 \mathrm{kWh} \mathrm{m}^{-3}$ per $1000 \mathrm{~m}$ elevation increase. Second, the results for Switzerland underline that significant annual HP reduction might result from glacier retreat already in the near future; the highlighted large regional differences call for more detailed studies in Europe and elsewhere.

\section{Acknowledgements}

The first two authors acknowledge the funding by the Swiss Competence Centre for Energy Research - Supply of Electricity (SCCER-SoE, Switzerland). The work of the last author was funded by the Swiss National Science Foundation (SNSF Ambizione Energy grant number 154290). The HydroGIS database was made available by M. Balmer. The meterological data (ANETZ stations) is available from MeteoSwiss (https://gate.meteoswiss.ch/idaweb), the topographical data by SwissTopo (no free distribution). We also would like to thank M. Zappa (WSL) for the monthly discharge data set (Zappa et al., 2012), which corresponds to an improved version of the dataset that is currently published by the Swiss Federal Office for the environment (Pfaundler and Schönenberger, 2013) here: www.bafu.admin.ch/mq-gwn-ch-e 


\section{References}

Addor, N., Rössler, O., Köplin, N., Huss, M., Weingartner, R., and Seibert, J.: Robust changes and sources of uncertainty in the projected hydrological regimes of Swiss catchments, Water Resources Research, 50, 7541-7562, 10.1002/2014WR015549, 2014.

Balmer, M.: Nachhaltigkeitsbezogene Typologisierung der schweizerischen Wasserkraftanlagen GIS-basierte Clusteranalyse und Anwendung in einem Erfahrungskurvenmodell, ETHZ, Zürich, 2012.

Barnett, T. P., Adam, J. C., and Lettenmaier, D. P.: Potential impacts of a warming climate on water availability in snow-dominated regions, Nature, 438, 303-309, 2005.

Bauermann, K., Spiecker, S., and Weber, C.: Individual decisions and system development Integrating modelling approaches for the heating market, Appl. Energy, 116, 149-158, https://doi.org/10.1016/j.apenergy.2013.11.046, 2014.

Beck, M., and Scherer, M.: SwissGrid - Overview of ancillary services, available at https://www.swissgrid.ch/dam/swissgrid/experts/ancillary services/Dokumente/D100412 ASconcept V1R0 en.pdf, last accessed 23 january 2018, Frick, Switzerland, 6, 2010.

Blanc, P., and Schädler, B.: Water in Switzerland - an overview, available in English on http://www.naturalsciences.ch/topics/water/ (accessed 18.08.2015), Bern, 28, 2013.

Bolch, T., Kulkarni, A., Kääb, A., Huggel, C., Paul, F., Cogley, J. G., Frey, H., Kargel, J. S., Fujita, K., Scheel, M., Bajracharya, S., and Stoffel, M.: The State and Fate of Himalayan Glaciers, Science, 336, 310-314, 10.1126/science.1215828, 2012.

Bradley, R. S., Vuille, M., Diaz, H. F., and Vergara, W.: Threats to Water Supplies in the Tropical Andes, Science, 312, 1755-1756, 10.1126/science.1128087, 2006.

Dee, D. P., Uppala, S. M., Simmons, A. J., Berrisford, P., Poli, P., Kobayashi, S., Andrae, U., Balmaseda, M. A., Balsamo, G., Bauer, P., Bechtold, P., Beljaars, A. C. M., van de Berg, L., Bidlot, J., Bormann, N., Delsol, C., Dragani, R., Fuentes, M., Geer, A. J., Haimberger, L., Healy, S. B., Hersbach, H., Holm, E. V., Isaksen, L., Kallberg, P., Kohler, M., Matricardi, M., McNally, A. P., Monge-Sanz, B. M., Morcrette, J. J., Park, B. K., Peubey, C., de Rosnay, P., Tavolato, C., Thepaut, J. N., and Vitart, F.: The ERA-Interim reanalysis: configuration and performance of the data assimilation system, Quarterly Journal of the Royal Meteorological Society, 137, 553-597, 10.1002/qj.828, 2011.

Farinotti, D., Usselmann, S., Huss, M., Bauder, A., and M., F.: Runoff evolution in the Swiss Alps: projections for selected high-alpine catchments based on ENSEMBLES scenarios, Hydrological Processes, 26, 1909-1924, 10.1002/hyp.8276, 2012.

Farinotti, D., Pistocchi, A., and Huss, M.: From dwindling ice to headwater lakes: could dams replace glaciers in the European Alps?, Environmental Research Letters, 11, 054022, 2016.

Fatichi, S., Rimkus, S., Burlando, P., Bordoy, R., and Molnar, P.: High-resolution distributed analysis of climate and anthropogenic changes on the hydrology of an Alpine catchment, Journal of Hydrology, 525, 362-382, http://dx.doi.org/10.1016/i.jhydrol.2015.03.036, 2015.

Finger, D., Heinrich, G., Gobiet, A., and Bauder, A.: Projections of future water resources and their uncertainty in a glacierized catchment in the Swiss Alps and the subsequent effects on hydropower production during the 21st century, Water Resources Research, 48, W02521, 10.1029/2011wr010733, 2012.

Fischer, M., Huss, M., Barboux, C., and Hoelzle, M.: The New swiss glacier inventory SGI2010: relevance of using high-resolution source data in areas dominated by very small glaciers, Arctic, Antarctic, and Alpine Research, 46, 933-945, 2014.

Fischer, M., Huss, M., and Hoelzle, M.: Surface elevation and mass changes of all Swiss glaciers 19802010, Cryosphere, 9, 525-540, 10.5194/tc-9-525-2015, 2015.

FOEN: Effects of Climate Change on Water Resources and Waters. Synthesis report on "Climate Change and Hydrology in Switzerland" (CCHydro) project. Results also available at https://hydro.slf.ch/sihl/cchydro/\# (accessed 26 Feb. 2016), Federal Office for the Environment,, Bern, 74, 2012. 
Gabbi, J., Farinotti, D., Bauder, A., and Maurer, H.: Ice volume distribution and implications on runoff projections in a glacierized catchment, Hydrol. Earth Syst. Sci., 16, 4543-4556, 10.5194/hess-164543-2012, 2012.

Gaudard, L., Romerio, F., Dalla Valle, F., Gorret, R., Maran, S., Ravazzani, G., Stoffel, M., and Volonterio, M.: Climate change impacts on hydropower in the Swiss and Italian Alps, Sci. Total Environ., 493, 1211-1221, 10.1016/j.scitotenv.2013.10.012, 2014.

Gernaat, D., Bogaart, P. W., van Vuuren, D. P., Biemans, H., and Niessink, R.: High-resolution assessment of global technical and economic hydropower potential, Nature Energy, 2, 10.1038/s41560-017-0006-y, 2017.

Grande Dixence: Grande Dixence - a legend in the heart of the Alps. http://www.grandedixence.ch/template/fs/documents/70p A4-v3 2010 EN.pdf, accessed 09 dec 2015, Grande Dixence SA, Sion, 72, 2010.

Gurung, A. B., Borsdorf, A., Fureder, L., Kienast, F., Matt, P., Scheidegger, C., Schmocker, L., Zappa, M., and Volkart, K.: Rethinking Pumped Storage Hydropower in the European Alps A Call for New Integrated Assessment Tools to Support the Energy Transition, Mountain Research and Development, 36, 222-232, 10.1659/mrd-journal-d-15-00069.1, 2016.

Hamududu, B., and Killingtveit, A.: Assessing Climate Change Impacts on Global Hydropower, Energies, 5, 305-322, 10.3390/en5020305, 2012.

Hänggi, P., and Weingartner, R.: Variations in Discharge Volumes for Hydropower Generation in Switzerland, Water Resour. Manag., 26, 1231-1252, 10.1007/s11269-011-9956-1, 2012.

Horton, P., Schaefli, B., Hingray, B., Mezghani, A., and Musy, A.: Assessment of climate change impacts on Alpine discharge regimes with climate model uncertainty, Hydrological Processes, 20, 2091-2109, 2006.

Huss, M., Farinotti, D., Bauder, A., and Funk, M.: Modelling runoff from highly glacierized alpine drainage basins in a changing climate, Hydrological Processes, 22, 3888-3902, 10.1002/hyp.7055, 2008.

Huss, M., Jouvet, G., Farinotti, D., and Bauder, A.: Future high-mountain hydrology: a new parameterization of glacier retreat, Hydrology and Earth System Sciences, 14, 815-829, 10.5194/hess-14-815-2010, 2010.

Huss, M.: Present and future contribution of glacier storage change to runoff from macroscale drainage basins in Europe, Water Resour. Res., 47, W07511, 10.1029/2010wr010299, 2011.

Huss, M., Zemp, M., Joerg, P. C., and Salzmann, N.: High uncertainty in 21st century runoff projections from glacierized basins, Journal of Hydrology, 510, 35-48, 10.1016/j.jhydrol.2013.12.017, 2014.

Huss, M., and Hock, R.: A new model for global glacier change and sea-level rise, Frontiers in Earth Science, 3, 10.3389/feart.2015.00054, 2015.

Kao, S. C., Sale, M. J., Ashfaq, M., Martinez, R. U., Kaiser, D. P., Wei, Y. X., and Diffenbaugh, N. S.: Projecting changes in annual hydropower generation using regional runoff data: An assessment of the United States federal hydropower plants, Energy, 80, 239-250, 10.1016/j.energy.2014.11.066, 2015.

Kummer, M., Baumgartner, M., and Devanthéry, D.: Restwasserkarte. Schweiz. Wasserentnahmen und -rückgaben. (available http://www.bafu.admin.ch/publikationen/publikation/00052/index.html?lang=fr, accessed 03.12.2015)

Swiss Federal Office for the Environment, Bern, Switzerland, 90, 2007.

Langhammer, L., Rabenstein, L., Bauder, A., and Maurer, H.: Ground-penetrating radar antenna orientation effects on temperate mountain glaciers, Geophysics, 82, H15-H24, 10.1190/geo20160341.1, 2017.

Lehner, B., Czisch, G., and Vassolo, S.: The impact of global change on the hydropower potential of Europe: a model-based analysis, Energy Policy, 33, 839-855, https://doi.org/10.1016/j.enpol.2003.10.018, 2005. 
Manso, P., Schaefli, B., and Schleiss, A. J.: Adaptation of Swiss hydropower infrastructure to meet future electricity needs, Hydro 2015, Advancing policy and practice, Bordeaux, 26 - 28 Oct. 2015, 2015,

Orlove, B.: GLACIER RETREAT Reviewing the Limits of Human Adaptation to Climate Change, Environment, 51, 22-34, 10.3200/envt.51.3.22-34, 2009.

Pfaundler, M., and Zappa, M.: Die mittleren Abflüsse über die ganze Schweiz - Ein optimierter Datensatz im 500×500 m Raster, available on http://www.bafu.admin.ch/hydrologie, 2008.

Pfaundler, M., and Schönenberger, U.: Dataset MQ-GWN-CH, modeled natural runoff means for the Swiss river network, available at www.bafu.admin.ch/mq-gwn-ch-e (accessed 14 July 2016), Swiss Federal Office for the Environment, FOEN, Bern, 2013.

Schädler, B., and Weingartner, R.: Components of the natural water balance. Hydrologic atlas of Switzerland - Plate 6.3. Available at http://www.hades.unibe.ch/ (accessed 01.03.2016), Service Hydrologique et Géologique National (SHGN), Bern, 2002.

Schaefli, B., Hingray, B., and Musy, A.: Climate change and hydropower production in the Swiss Alps: quantification of potential impacts and related modelling uncertainties, Hydrology and Earth System Sciences, 11, 1191-1205, 10.5194/hess-11-1191-2007, 2007.

Schaefli, B.: Projecting hydropower production under future climates: a guide for decision-makers and modelers to interpret and design climate change impact assessments, WIREs Water, 2, 271289, 10.1002/wat2.1083, 2015.

SGHL, and CHy: Auswirkungen der Klimaänderung auf die Wasserkraftnutzung - Synthesebericht, Swiss Society of Hydrology and Limnology (SGHL) and Swiss Hydrological Commission (CHy), Bern, 28, 2011.

Speich, M. J. R., Bernhard, L., Teuling, A. J., and Zappa, M.: Application of bivariate mapping for hydrological classification and analysis of temporal change and scale effects in Switzerland, Journal of Hydrology, 523, 804-821, 10.1016/j.jhydrol.2015.01.086, 2015.

Suter, S., Konzelmann, T., Mühlhäuser, C., Begert, M., and Heimo, A.: SWISSMETNET - The new automatic meteorological network of Switzerland: transition from old to new network, data management and first results, available on http://www.meteoschweiz.admin.ch/web/, Zurich, 2006.

Swiss Federal Office for Energy: Statistics of the Swiss hydropower facilities - Statistik der Wasserkraftanlagen der Schweiz (WASTA), state 01. 01. 2015, available on http://www.bfe.admin.ch/, Swiss Federal Office for Energy, Bern, Switzerland, 2015.

Swiss Federal Office for Energy: Swiss Electricity statistics 2015, available at http://www.bfe.admin.ch/themen/00526/00541/00542/00630/index.html?lang=en (accessed 14. July 2016), Swiss Federal Office for Energy, Bern, 56, 2016.

Swiss Federal Office for Energy: Dams and reservoirs under the supervision of the federal government, http://www.bfe.admin.ch, Home > Topics > Supervision and Safety > Dams, state 19. 12. 2016 (last accessed 25 Sept. 2017), Swiss Federal Office for Energy, Bern, Switzerland, 2017a.

Swiss Federal Office for Energy: Statistics of the Swiss hydropower facilities - Statistik der Wasserkraftanlagen der Schweiz (WASTA), state 01. 01. 2017, available on http://www.bfe.admin.ch/geoinformation/05061/05249/index.html?lang=de\&dossier id=01049 (last accessed 25 Sept. 2017), Swiss Federal Office for Energy, Bern, Switzerland, 2017b.

Swiss Federal Office for Energy: Swiss Electricity statistics 2016. Annual report available at http://www.bfe.admin.ch/themen/00526/00541/00542/00630/index.html?lang=en (accessed 25 Sept. 2017); time series available upon direct request., Swiss Federal Office for Energy, Bern, 56, 2017c.

Mean monthly and annual runoff depths, digital data set, available at: http://www.bafu.admin.ch/wasser/13462/13496/15015/index.html?lang=en (accessed 01.03.2016), 2016.

SwissTopo: DHM25- The digital height model of Switzerland, Wabern, Switzerland, 2005. SwissTopo: Vector25 - The digital landscape model of Switzerland, Wabern, Switzerland, 2008. 
Taylor, K. E., Stouffer, R. J., and Meehl, G. A.: An overview of CMIP5 and the experiment Bulletin of the American Meteorological Society, 93, 485-498, 10.1175/bams-d-11-00094.1, 2012.

Terrier, S., Bieri, M., Jordan, F., and Schleiss, A. J.: Impact of glacier shrinkage and adapted hydropower potential in the Swiss Alps, Houille Blanche-Rev. Int., 93-101, 10.1051/lhb/2015012, 2015.

Tonka, L.: Hydropower license renewal and environmental protection policies: a comparison between Switzerland and the USA, Reg Environ Change, 15, 539-548, 10.1007/s10113-014-0598-8, 2015.

Vergara, W., Deeb, A., Valencia, A., Bradley, R., Francou, B., Zarzar, A., Grünwaldt, A., and Haeussling, S.: Economic impacts of rapid glacier retreat in the Andes, EOS, Transactions American Geophysical Union, 88, 261-264, 10.1029/2007eo250001, 2007.

Voisin, N., Kintner-Meyer, M., Skaggs, R., Nguyen, T., Wu, D., Dirks, J., Xie, Y., and Hejazi, M.: Vulnerability of the US western electric grid to hydro-climatological conditions: How bad can it get?, Energy, 115, 1-12, 10.1016/j.energy.2016.08.059, 2016.

Wagner, T., ThemeßI, M., Schüppel, A., Gobiet, A., Stigler, H., and Birk, S.: Impacts of climate change on stream flow and hydro power generation in the Alpine region, Environmental Earth Sciences, 76, 4, 10.1007/s12665-016-6318-6, 2016.

Weingartner, R., and Aschwanden, $\mathrm{H}$.: Discharge regime - the basis for the estimation of average flows. Plate 5.2, Hydrological Atlas of Switzerland, http://hades.unibe.ch, in, edited by: Weingartner, R., and Spreafico, M., Swiss National Hydrological and Geological Survey, Berne, 1992.

Zappa, M., Bernhard, L., Fundel, F., and Joerg-Hess, S.: Vorhersage und Szenarien von Schnee- und Wasserressourcen im Alpenraum. Data set available from the lead author., Forum für Wissen, 1927, 2012. 
This is a preprint of a manuscript submitted to Renewable Energy , 30 January 2018, with corrected figure 8

\section{Tables}

Table 1: Overview of Swiss annual hydropower production (1980 - 2016), including energy consumption for water pumping from lower to upper reservoirs (Swiss Federal Office for Energy, 2016).

\begin{tabular}{|l|r|}
\hline Hydropower production & ${\text { TWh } \mathrm{yr}^{-1}}^{-1}$ \\
\hline Average production & 35.7 \\
\hline Maximum (year 2001) & 42.3 \\
\hline Minimum (year 1996) & 29.7 \\
\hline Standard deviation & 3.0 \\
\hline $\begin{array}{l}\text { Average consumption for } \\
\text { pumping }\end{array}$ & 1.9 \\
\hline
\end{tabular}


Table 2: Properties of the electricity statistics regions, including the coefficient of variation (cv) of precipitation and the production potential; glacier cover indicates the relative glacier cover for the reference year 2010. The average values for the HP catchments are computed as the average of all scheme catchments of a region. The electricity coefficient is the average value of all powerhouses within a region. Production potential and precipitation data refer to period 1983-2014; normalization with the mean over this period.

\begin{tabular}{|c|c|c|c|c|c|c|c|c|c|}
\hline Region & $\begin{array}{c}\text { Total HP } \\
\text { catchment } \\
\text { area }\left(\mathrm{km}^{2}\right)\end{array}$ & $\begin{array}{c}\text { Joint area } \\
\left(\mathrm{km}^{2}\right)\end{array}$ & $\begin{array}{l}\text { \# power- } \\
\text { houses }\end{array}$ & $\begin{array}{l}\text { Average glacier } \\
\text { cover of HP } \\
\text { catchments (\%) }\end{array}$ & $\begin{array}{l}\text { Average elevation } \\
\text { of HP catchments } \\
\text { ( } m \text { asl.) }\end{array}$ & $\begin{array}{l}\text { Average elevation } \\
\text { of powerhouses } \\
\text { (m asl.) }\end{array}$ & $\begin{array}{l}\text { Normalized annual } \\
\text { production potential } \\
\text { [min, max] }\end{array}$ & $\begin{array}{l}\text { cV } \\
\text { production } \\
\text { potential }\end{array}$ & $\begin{array}{l}\text { CV } \\
\text { precipi- } \\
\text { tation }\end{array}$ \\
\hline $\begin{array}{l}\text { Switzerland } \\
(\mathrm{CH})\end{array}$ & 39741 & 528278 & 402 & 3.7 & 1742 & 752 & $(0.85,1.20)$ & 0.08 & 0.10 \\
\hline Grisons & 7088 & 10235 & 58 & 2.0 & 2162 & 1014 & $(0.77,1.41)$ & 0.14 & 0.10 \\
\hline Valais & 5200 & 27324 & 70 & 12.2 & 2414 & 773 & $(0.83,1.16)$ & 0.07 & 0.10 \\
\hline Ticino & 2735 & 2357 & 33 & 0.2 & 1816 & 1010 & $(0.63,1.36)$ & 0.16 & 0.11 \\
\hline Jura & 2532 & 7075 & 8 & 0.0 & 992 & 637 & $(0.68,1.36)$ & 0.15 & 0.11 \\
\hline Plateau & 10037 & 234419 & 147 & 1.3 & 1124 & 482 & $(0.87,1.14)$ & 0.07 & 0.11 \\
\hline North Alps & 12408 & 246868 & 86 & 2.3 & 1530 & 658 & $(0.86,1.15)$ & 0.06 & 0.12 \\
\hline
\end{tabular}


Table 3: Characteristic electricity coefficients (EC), computed at different levels. Area-scale ECs express how much hydropower is produced per $\mathrm{m}^{3}$ of water originating in that area, point -scale ECs express how much hydropower is produced per $\mathrm{m}^{3}$ transiting through that point. The weighing type indicates how the underlying data is weighed (design discharge is the design discharge of the turbines, exp. stands for expected and designates a design value rather than an actual observed value.

\begin{tabular}{|c|c|c|c|c|c|}
\hline EC name & Scale & Aggregation level & Underlying EC data & Weighing & $\mathrm{kWh} \mathrm{m} \mathrm{m}^{-3}$ \\
\hline Powerhouses, average $(n=284)$ & Point-scale & Powerhouses & Powerhouses & No weighing & 0.634 \\
\hline Powerhouses, $\max$ & Point-scale & Powerhouses & Powerhouses & Does not apply & 4.444 \\
\hline Powerhouses, $\min$ & Point-scale & Powerhouses & Powerhouses & Does not apply & 0.004 \\
\hline Schemes, average & Area-scale & Schemes & Powerhouses & Exp. production hours $x$ design discharge & 0.591 \\
\hline Grisons & Area-scale & Production region & Schemes & Exp. annual production & 0.856 \\
\hline Valais & Area-scale & Production region & Schemes & Exp. annual production & 1.707 \\
\hline Ticino & Area-scale & Production region & Schemes & Exp. annual production & 0.997 \\
\hline Jura & Area-scale & Production region & Schemes & Exp. annual production & 0.216 \\
\hline Plateau & Area-scale & Production region & Schemes & Exp. annual production & 0.020 \\
\hline North Alps & Area-scale & Production region & Schemes & Exp. annual production & 0.530 \\
\hline Switzerland & Area-scale & Switzerland & Schemes & Exp. annual production & 0.906 \\
\hline Rhine & Point-scale & Network & Powerhouses & Exp. production hours $x$ design discharge & 0.041 \\
\hline Rhine outlet, Birsfelden & Point-scale & Scheme & Powerhouses & Does not apply & 0.018 \\
\hline Rhone & Point-scale & Network & Powerhouses & Exp. production hours $x$ design discharge & 0.269 \\
\hline Rhone outlet, Chancy-Pougny & Point-scale & Scheme & Powerhouses & Does not apply & 0.021 \\
\hline $\mathrm{CH}$ glacier area & Area-scale & Switzerland & Regions & Interpolated from regions & 2.101 \\
\hline Rhine glacier area & Area-scale & Switzerland & Regions & Interpolated from regions & 1.892 \\
\hline Rhone glacier area & Area-scale & Switzerland & Regions & Interpolated from regions & 2.212 \\
\hline
\end{tabular}


Table 4: Observed average glacier mass balance changes (in $\mathrm{mm}$ of water equivalent) for Switzerland $(\mathrm{CH})$, the Rhine and the Rhone HP catchments at their outlet and the corresponding ratio of net annual ice melt to average annual discharge without considering HP nesting. A few glaciers are not included neither in the Rhine HP catchment nor in the Rhone HP network; some glacier water of the physiographic Rhone catchment is exported, i.e. does not feed the Rhone HP catchments (e.g. Gries).

\begin{tabular}{|l|c|c|c|c|c|c|c|c|c|}
\hline & $\begin{array}{c}\text { Area HP } \\
\text { production } \\
\text { catchments } \\
\left(\mathrm{km}^{2}\right)\end{array}$ & \multicolumn{2}{|c|}{$\begin{array}{c}\text { Annual glacier Mass } \\
\text { loss }\left(\mathrm{mm} \mathrm{yr}^{-1}\right)\end{array}$} & \multicolumn{2}{|c|}{ Glacier area $\left(\mathrm{km}^{2)}\right.$} & \multicolumn{2}{|c|}{$\begin{array}{c}\text { Avg discharge reference } \\
\text { period } \\
\left(\mathrm{mm} \mathrm{yr}^{-1}\right)\end{array}$} & $\begin{array}{c}\text { Ratio of annual glacier } \\
\text { mass loss to discharge } \\
(\%)\end{array}$ \\
\hline & & $1981-2000$ & $1981-2010$ & 1973 & 2010 & $1981-2000$ & $1981-2010$ & $1981-2000$ & $1981-2010$ \\
\hline $\mathrm{CH}$ & 39741 & 479 & 620 & 1261.2 & 942.8 & 1037 & 1013 & 1.3 & 1.7 \\
\hline Rhine & 26520 & 502 & 634 & 406.3 & 283.0 & 1007 & 984 & 0.65 & 0.8 \\
\hline Rhone & 7655 & 452 & 579 & 682.5 & 543.4 & 1109 & 1092 & 3.3 & 4.2 \\
\hline
\end{tabular}


Table 5: Estimated average HP ratios from glacier melt, $\bar{\rho}_{C H}$, estimated either from ratios of net glacier melt to total discharge (labeled discharge ratios) or from glacier-averaged electricity coefficient (see Table 3), labeled EC. Confidence limits (given in brackets) can be calculated for the EC method only; discharge-based estimations are weighted averages over the schemes, with weights corresponding to the expected annual production of each scheme. For the simulations, the net ice melt corresponds to the melt between two simulation time periods.

\begin{tabular}{|c|c|c|c|c|c|c|}
\hline Estimation method & $\begin{array}{c}\text { Reference period } \\
\text { simulation }\end{array}$ & Period & Source & $\bar{\rho}_{C H}(-)$ & $\bar{\rho}_{\text {Rhone }}(-)$ & $\bar{\rho}_{\text {Rhine }}(-)$ \\
\hline avg EC & & $1981-2000$ & Obs & $3.2(1.8,5.2)$ & $6.4(3.4,10.2)$ & $1.8(1.0,2.9)$ \\
\hline avg EC & & $1980-2010$ & Obs & $4.0(2.3,6.2)$ & $7.8(4.4,12.2)$ & $2.2(1.3,3.4)$ \\
\hline Discharge ratios & & $1981-2000$ & Obs & 3.1 & 7.0 & 1.5 \\
\hline Discharge ratios & & $1980-2010$ & Obs & 3.8 & 8.6 & 1.8 \\
\hline Discharge ratios & $2010-2020$ & $2040-2060$ & GloGEM & 2.5 & 7.1 & 0.4 \\
\hline Discharge ratios & $2040-2060$ & $2070-2090$ & GloGEM & 1.2 & 3.8 & 0.1 \\
\hline & $\begin{array}{c}\text { Expected production } \\
\text { GWh yr }\end{array}$ & 2005 & HYDROGIS & 36,458 & 10,341 & 18,931 \\
\hline & Avg HP GWh yr & $1981-2000$ & Electricity stat. & 34,738 & $9853^{-1}$ & $18,038^{*}$ \\
\hline & Avg HP GWh yr & $1980-2010$ & Electricity stat & 35241 & $9996 *$ & $18296^{*}$ \\
\hline & Avg glacier elevation & & SwissTopo & 3042 & 3170 & 2814 \\
\hline
\end{tabular}

*estimated by scaling the Swiss-wide production by the expected production 


\section{Figure captions}
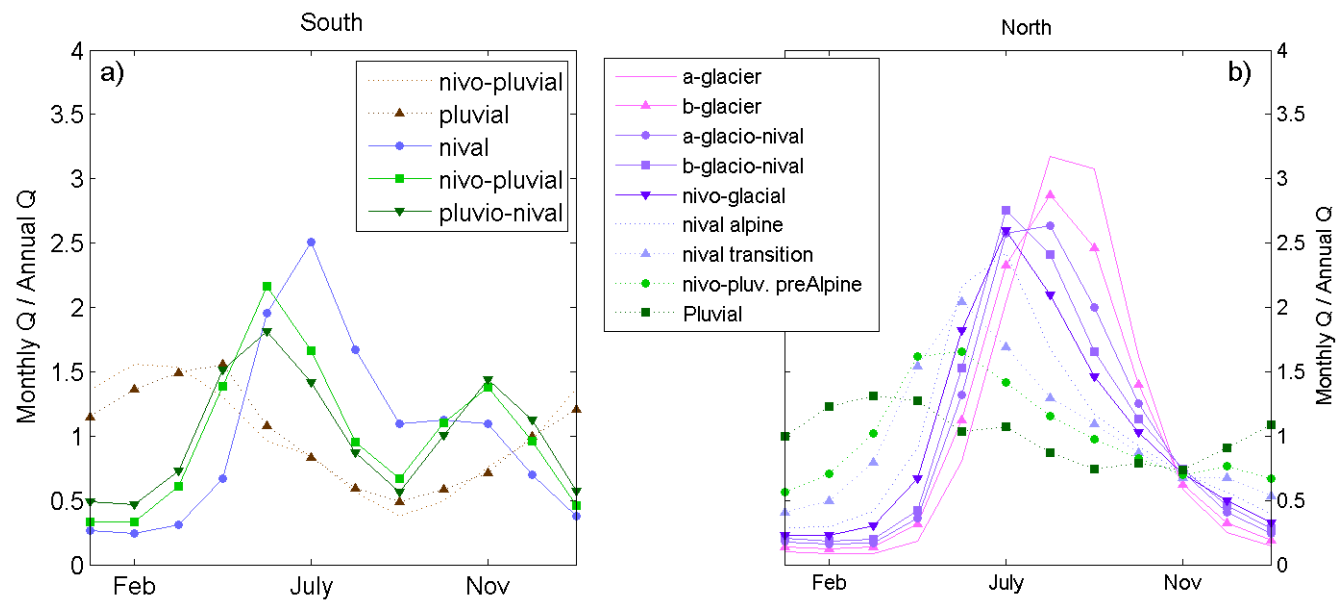

Figure 1: Swiss hydrological regimes in terms of the ratio between mean monthly streamflow and the mean annual streamflow (denoted as $Q$ ); a) for south of the Alps, b) for north of the Alps. Data source: (Pfaundler and Schönenberger, 2013).

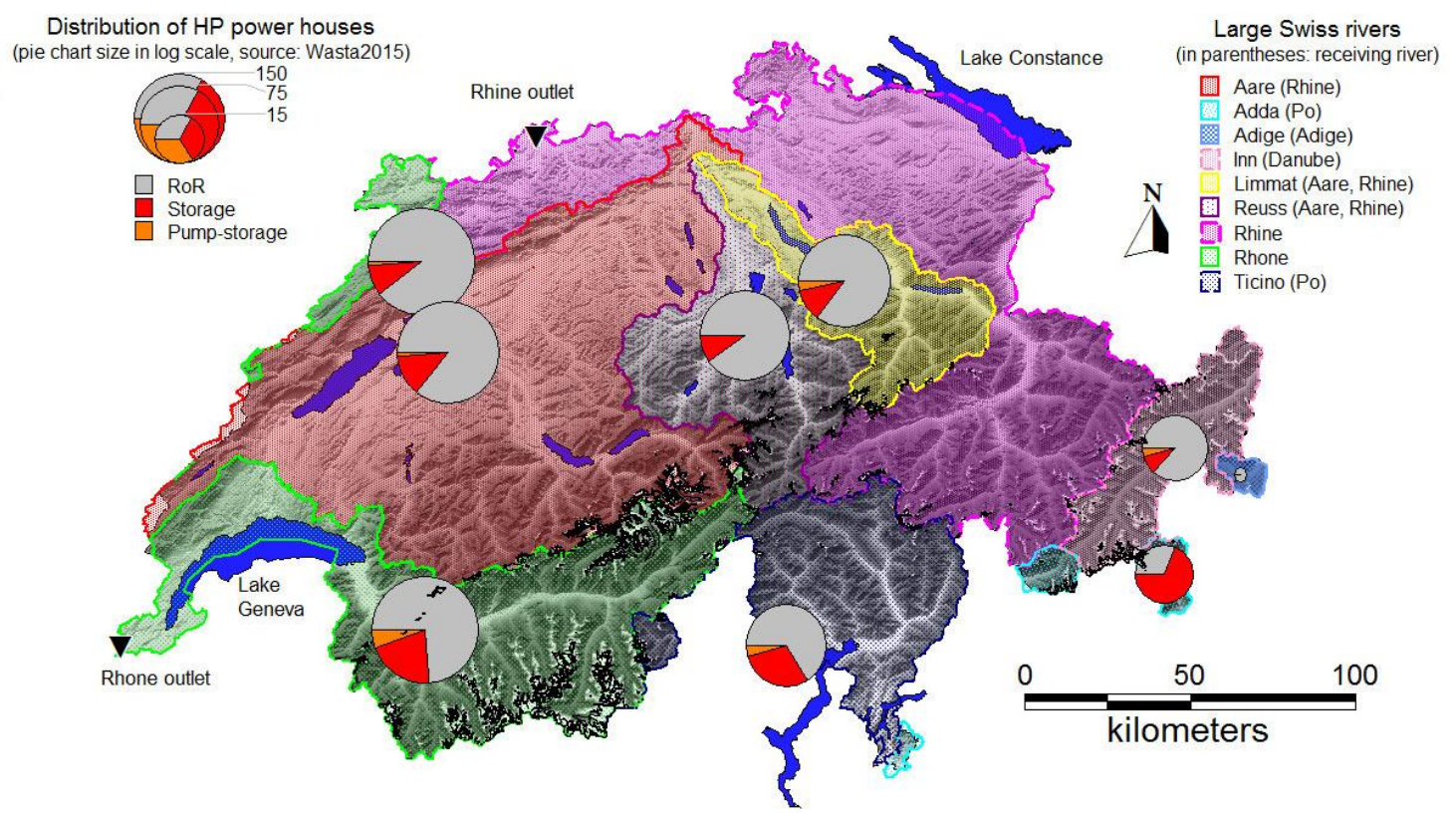

Figure 2: Distribution of main types of HP powerhouses according to the nine main Swiss river catchments; the Limmat and Reuss feed into the Aare river, which itself feeds into the Rhine river; own representation based on the HP powerhouse type and feeding catchment contained in (WASTA, Swiss Federal Office for Energy, 2015); other data sources: glacier outline (Fischer et al., 2014), digital elevation model (SwissTopo, 2005), lake vector data: (SwissTopo, 2008), catchment vector data: Swiss Hydrological Atlas HADES (Schädler and Weingartner, 2002) 

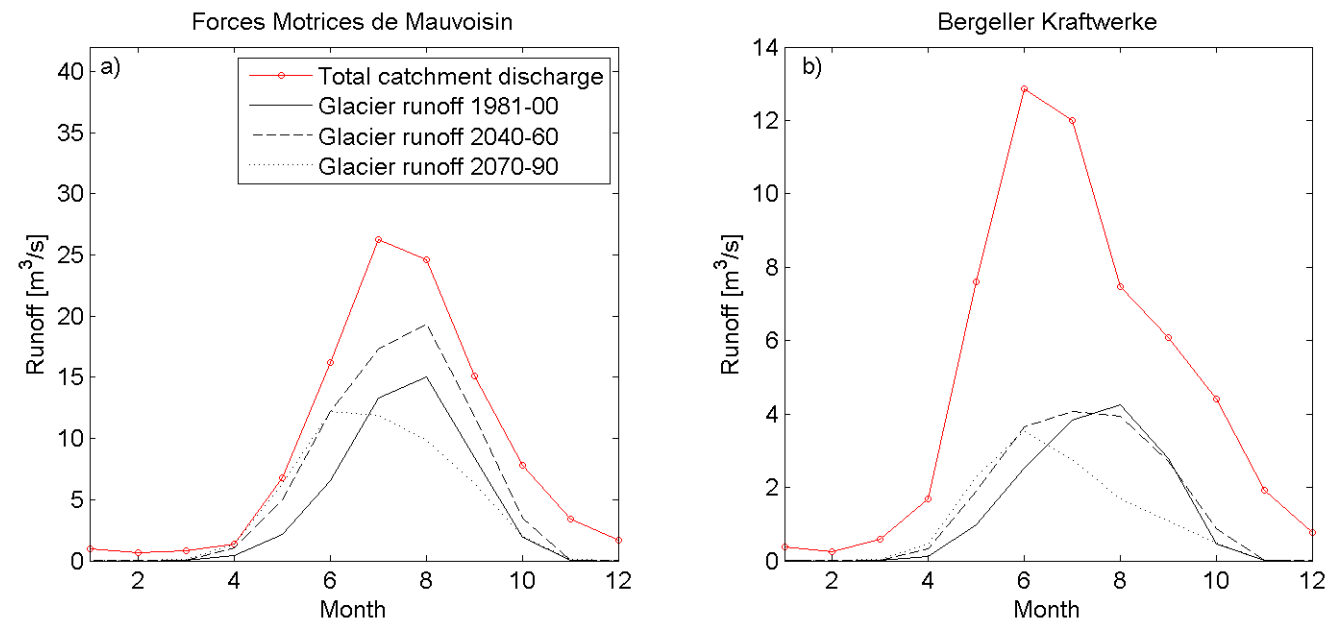

Figure 3: Present and future glacier runoff compared to the catchment discharge for the reference period for two selected HP catchments: a) Mauvoisin HP scheme located in the Upper Rhone River catchment; b) Bergeller HP scheme located in the Adda catchment (see Figure 2). Data source: glacier runoff (Huss and Hock, 2015), catchment discharge (Zappa et al., 2012). 

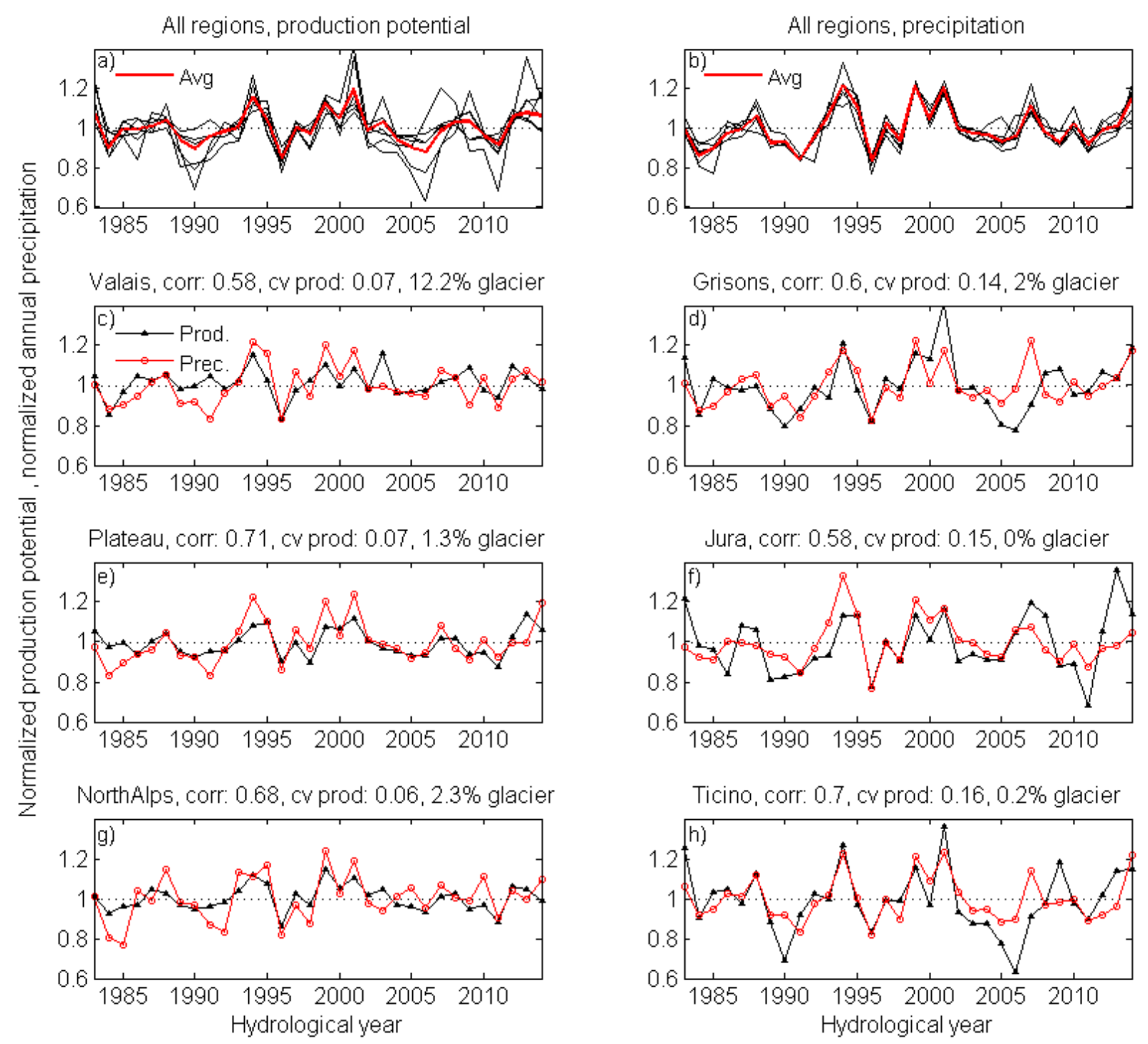

Grisons, corr: 0.6 , c prod: $0.14,2 \%$ glacier
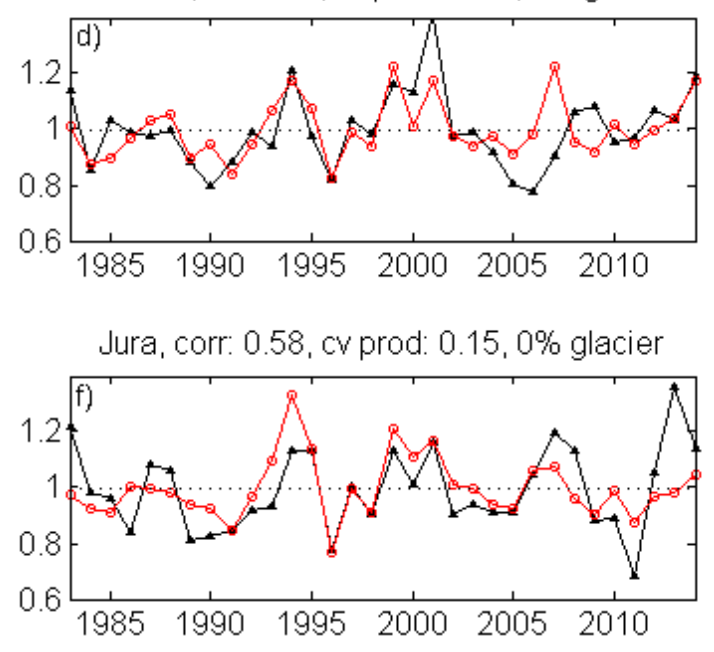

Ticino, corr: 0.7 , c prod: $0.16,0.2 \%$ glacier

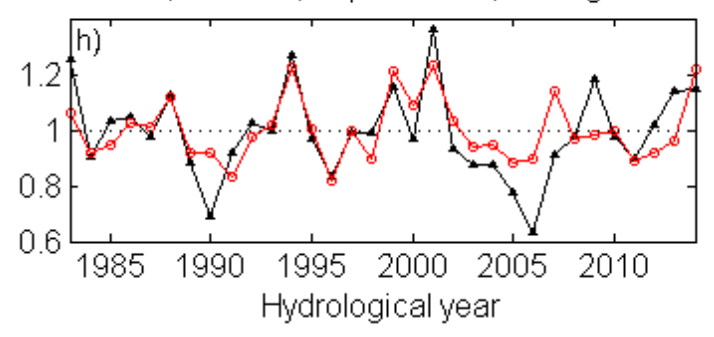

Figure 4: Normalized annual production potential and annual precipitation (with reference to the average value for the period 1983 - 2014): a) production potential for each of the six regions used in the electricity statistics and country-average, b) precipitation for each region and country-average (data as recorded at the SwissMetNet stations, (Suter et al., 2006), c) to h) production potential and precipitation per region; given is also the correlation between production potential and precipitation (corr), the coefficient of variation of the production potential ( $c$ v prod) and the degree of glacier cover. The hydrological year starts on 1 Oct. 

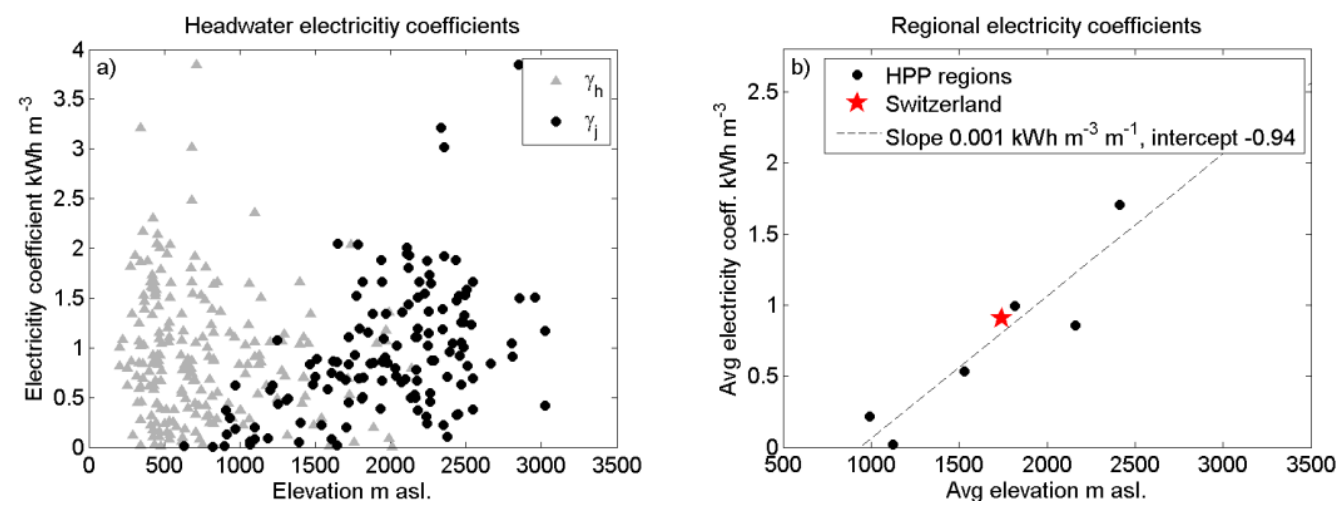

Figure 5: Relationship between elevation and electricity coefficients: a) electricity coefficients at the scale of headwater catchments; shown are the power house electricity coefficients $\gamma_{h}$ against power house elevation and the scheme-scale electricity coefficients $\gamma_{j}$ against catchment elevation; b) regional electricity coefficients, $\gamma_{r}$, for the six HP regions and for entire Switzerland against average scheme catchment elevation.

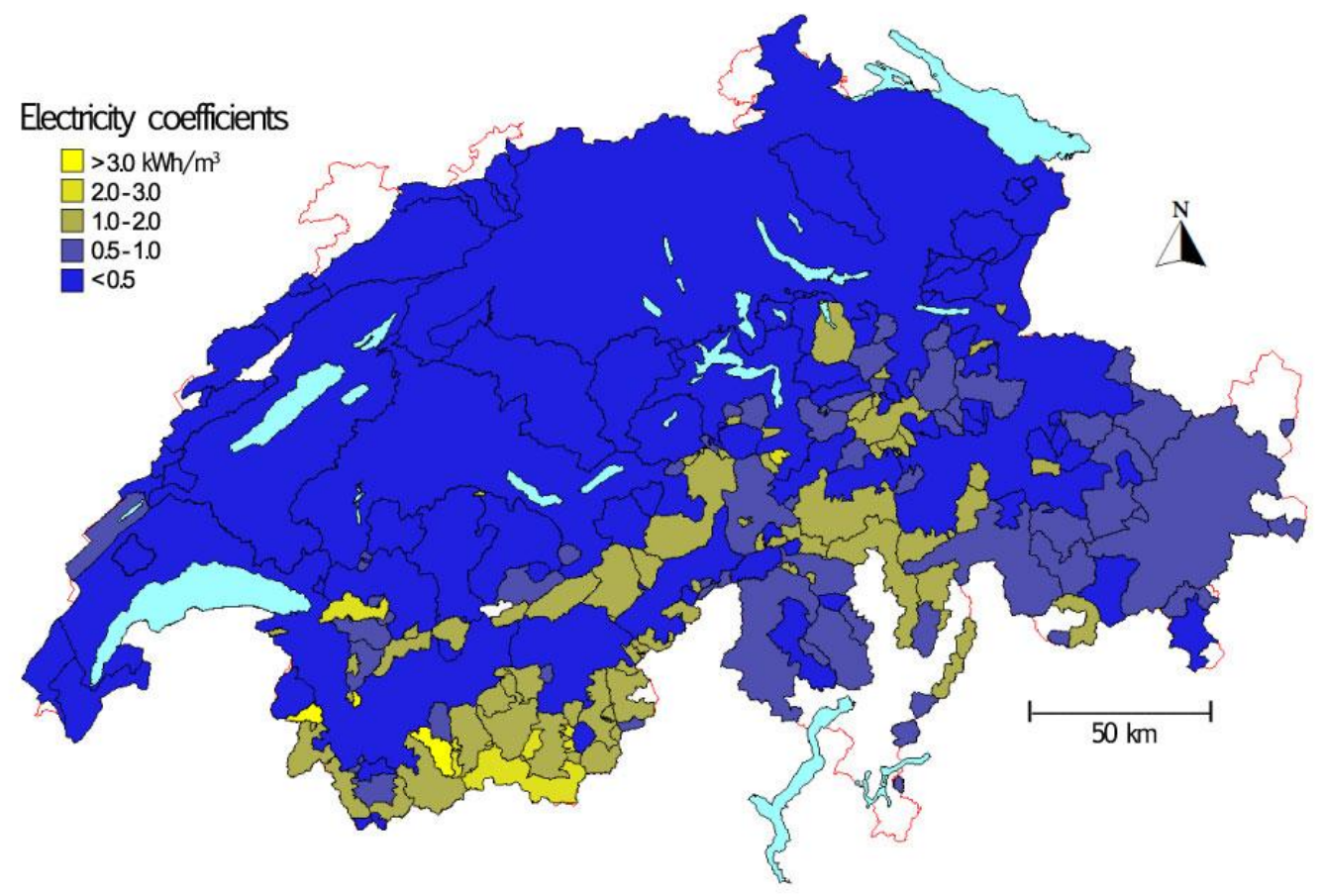

Figure 6: Spatial distribution of electricity coefficients of all HP schemes. The catchments are nested, lowland RoR catchments contain upstream catchments. 

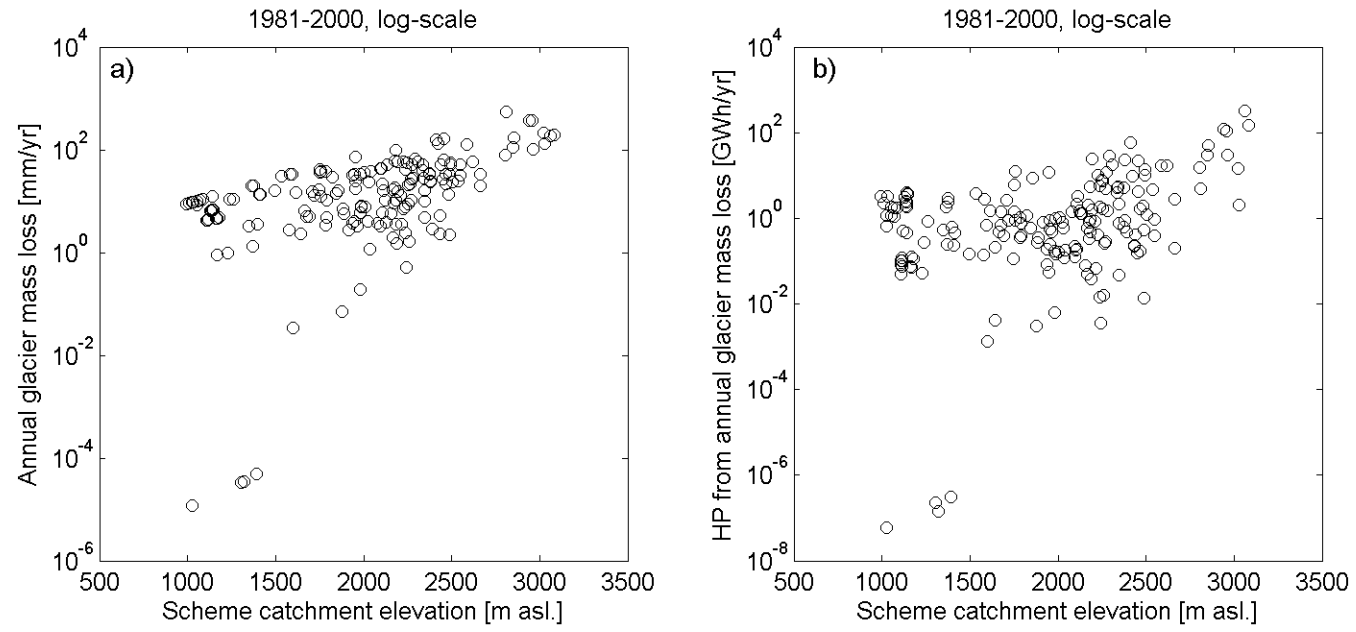

Figure 7: Annual glacier mass loss and corresponding hydropower production as a function of scheme catchment elevation for the period 1981-2000; a) annual glacier mass loss in $\mathrm{mm} \mathrm{yr}^{-1}$ (log-scale) b) estimated hydropower production from annual glacier mass loss (multiplied with the electricity coefficient $\gamma_{j}$ ) in $\mathrm{GWh} \mathrm{yr}^{-1}$.

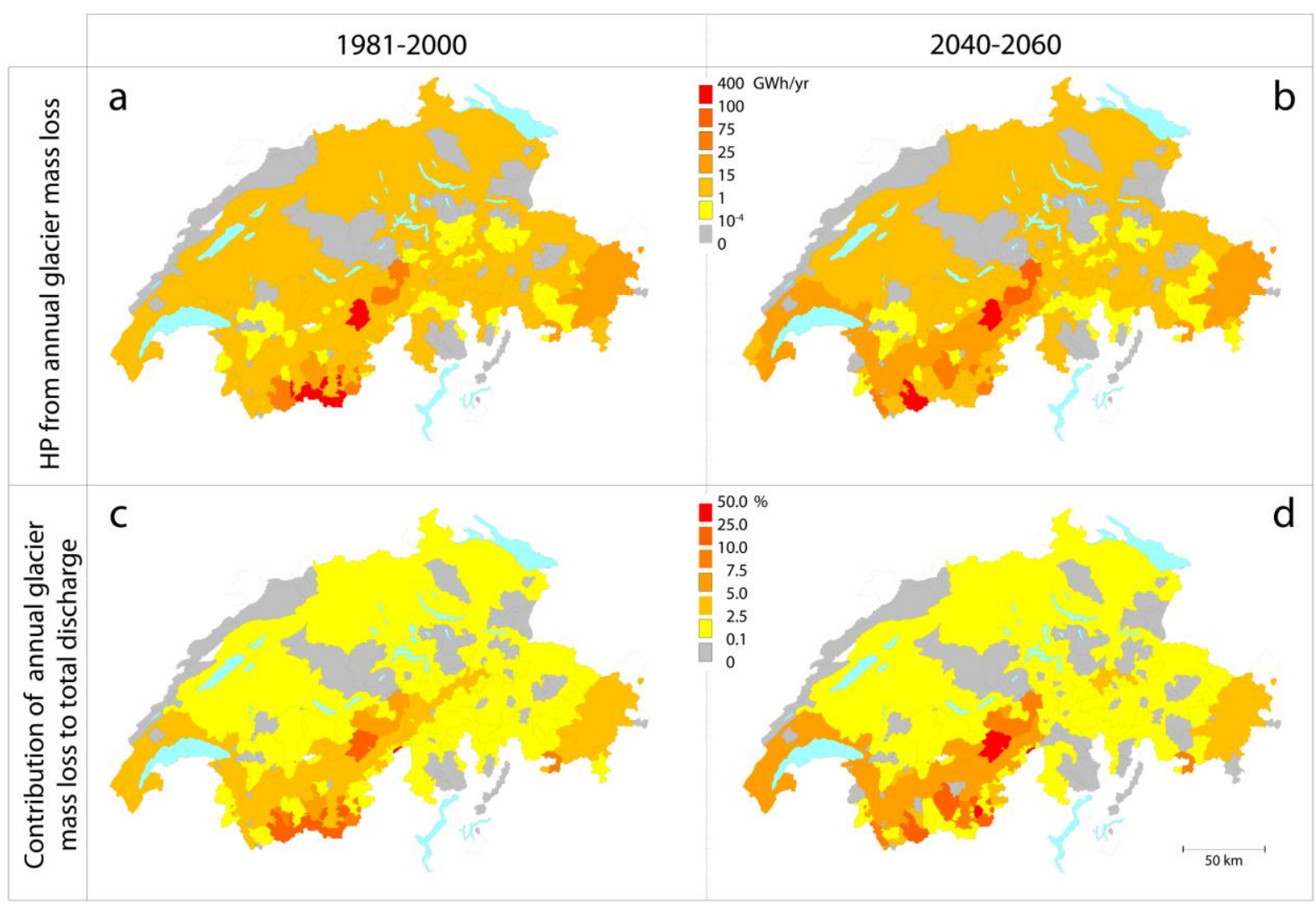

Figure 8 (corrected): Spatial distribution of the hydropower production from glacier mass

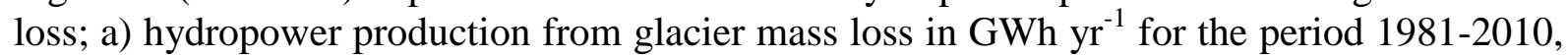
b) for the period 2040-2060 based on GloGEM simulations, c) ratios $\rho_{i j}$ for the period 19812000 , d) ratios for the period 2040-2060 based on GloGEM simulations. 

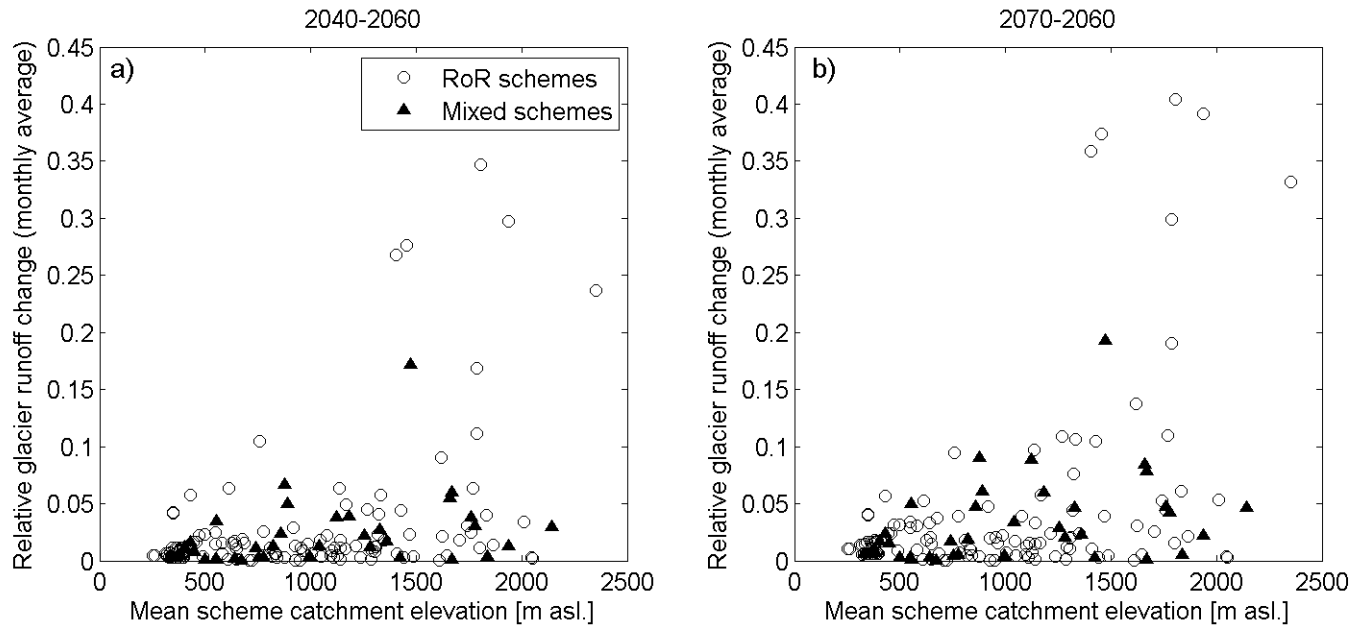

Figure 9: Glacier runoff change ratios $\left(\delta_{i j}\right)$ for all schemes that had glaciers during the reference period, plotted against scheme catchment elevation: left, period 2040-2060; right, period 2070-2090. The reference period is 1981-2000 for both future periods. Mixed schemes have run-of-river (RoR) and (pump-)storage hydropower production. 